\title{
0355. Optimal chest compression technique for pediatric arrest victims
}

\author{
MJ Kim, YS Park \\ From ESICM LIVES 2014 \\ Barcelona, Spain. 27 September - 1 October 2014
}

\begin{abstract}
Introduction
In pediatric cardiopulmonary resuscitation (CPR), highquality chest compressions (CCs) are essential to successful resuscitation, although most pediatric arrests are caused by respiratory arrest. Therefore, current guidelines emphasize deeper and faster CCs, with complete chest recoil between contractions. ${ }^{1,2}$ These guidelines further indicate that rescuers may use a one-hand or two-hand technique for pediatric compressions, thereby allowing rescuers to adapt the technique to the victim's size and rescuer's strength. However, no previous studies have examined the quality of CCs, including the use of deeper and faster CCs with complete chest recoil emphasized in the guidelines. Additionally, no study has assessed compression quality of the one-hand technique comparing the right and left hands.
\end{abstract}

\section{Objectives}

The aim of this study was to assess the quality of CCs performed by inexperienced rescuers using three different techniques: two-hand (2H), right one-hand (R1), and left one-hand (L1).

\section{Methods}

We performed a prospective, randomized, crossover study in a simulated 6-year-old pediatric manikin model. Each participant performed 2-minute continuous CCs, using three different techniques ( $2 \mathrm{H}, \mathrm{R} 1$, and $\mathrm{L} 1)$. CC quality data, including compression rate, compression depth, and leaning, were collected and analyzed. To examine trends in CC performance over time, each 2-minute period was divided into six consecutive 20-second epochs.

\section{Results}

The 36 participants completed 108 two-minute trials, consisting of a total of 25,030 CCs. The mean compression rates $(95 \%$ confidence interval $[\mathrm{CI}])$ were as follows: 2H1, 116.8 compressions/minute (111.7-121.9); L1, 115.0 compressions/minute (109.9-120.1); and R1, 115.5 compressions/minute (110.4-120.6) $(\mathrm{p}=0.565)$. The mean compression depth for $2 \mathrm{H}$ was $38.7 \mathrm{~mm}$ (37.1-40.2), which was higher than for L1 (36.3 mm [34.8-37.9]) or $\mathrm{R} 1$ (35.4 $\mathrm{mm}$ [33.9-37.0]) ( $<<0.001)$. The leaning rate was higher with $2 \mathrm{H}$ than $\mathrm{L} 1$ or $\mathrm{R} 1$ ( $\mathrm{p}=0.021)$. Chest compression depth per 20-second epoch declined over time, regardless of the technique $(\mathrm{p}<0.001)$. The pattern of compression depth change over time was similar for all techniques $(\mathrm{p}>0.999)$.

\section{Conclusions}

For pediatric cardiopulmonary resuscitation by inexperienced rescuers, the two hand $\mathrm{CC}$ technique has the advantage of producing deeper compressions than the one-hand technique, but it is accompanied by more frequent leaning. For the one-hand techniques, the right and left hand produced CCs of similar quality.

Grant acknowledgment

None.

Published: 26 September 2014

\section{References}

1. Biarent D, Bingham R, Eich C, et al: European Resuscitation Council guidelines for resuscitation 2010 section 6. paediatric life support. Resuscitation 2010, 81:1364-88.

2. Berg MD, Schexnayder SM, Chameides $L$, et al: Part 13: Pediatric basic life support: 2010 American Heart Association guidelines for cardiopulmonary resuscitation and emergency cardiovascular care. Circulation 2010, 18 Suppl 3:S862-75. 
doi:10.1186/2197-425X-2-S1-P21

Cite this article as: Kim and Park: 0355. Optimal chest compression

technique for pediatric arrest victims. Intensive Care Medicine Experimental 2014 2(Suppl 1):P21.
Submit your manuscript to a SpringerOpen ${ }^{\odot}$ journal and benefit from:

- Convenient online submission

- Rigorous peer review

- Immediate publication on acceptance

- Open access: articles freely available online

- High visibility within the field

- Retaining the copyright to your article

Submit your next manuscript at $>$ springeropen.com 